\title{
PENGARUH MOTIVASI DAN KEPUASAN KERJA TERHADAP KINERJA KARYAWAN PADA PT. RIAU POWER PEKANBARU
}

\author{
Nurhayana \\ Sekolah Tinggi Ilmu Ekonomi Riau \\ E-mail: nurhayana@ lecturer.stieriau-akbar.ac.id
}

\begin{abstract}
The purpose of this study was to determine the effect of motivation and job satisfaction on the performance of employees of PT. Riau Power Pekanbaru. The population of data collected in the study were all 34 employees. The sampling technique used is the census technique, which is used when the population is all sampled, to determine the results using SPSS as an analysis tool. The results of the study stated that motivation and job satisfaction partially and simultaneously had a positive and significant effect on performance, and the coefficient of determination of $66 \%$ and $34 \%$ was influenced by other variables not examined in this study.
\end{abstract}

Keywords: Motivasi, Kepuasan Kerja

\section{A. PENDAhULUAN}

Peranan sumber daya manusia dalam perusahaan sangatlah penting karena penggerak utama seluruh kegiatan atau aktivitas perusahaan dalam mencapai tujuannya baik untuk memperoleh keuntungan maupun untuk mempertahankan kelangsungan hidup perusahaan. Berhasil tidaknya suatu perusahaan dalam mempertahankan kegiatannya dimulai dari manusia itu sendiri dalam meningkatkan kineja secara maksimal. Sehubungan dengan itu kegiatan pertama dalam manajemen sumber daya manusia mendapatkan orangorang berkualitas. Karyawan hendaknya ditempatkan pada jabatan yang dapat mendorong dia untuk mnegembangkan diri dan setiap terdapat suatu masalah yang timbul pemimpin berperan untuk memotivasi karyawannya agar kinerja karyawannya tetap optimal dikarenakan motivasi merupakan dorongan atau semangat yang biasa timbul dalam diri seseorang.

Motivasi karyawan dilakukan dengan memberikan imbalan yang lebih atas kinerja yang diraih. Semakin tinggi kinerja karyawan semakin besar imbalan yang akan diterimanya. Selain itu motivasi berupa fasilitas, tempat kerja yang nyaman dan pemberian penghargaan atas prestasi kerja yang dicapai akan meningkatkan kinerja karyawan dalam melaksanakan tugasnya.Kinerja merupakan suatu fungsi dari motivasi dan kemampuan. Untuk menyelesaikan tugas atau pekerjaan seseorang sepatutnya memiliki derajat kesediaan dan tingkat kemampuan tertentu. Kesediaan dan keterampilan seseorang tidaklah cukup efektif untuk mengerjakan sesuatu tanpa pemahaman yang jelas tentang apa yang dikerjakan dan bagaimana mengerjakannya. Motivasi kerja yang rendah dapat menyebabkan menurunnya kepuasan kerja.

Menurut Veithzal Rivai (2011:856) mengatakan "Kepuasan kerja adalah evaluasi yang menggambarkan seseorang atas perasaan sikapnya senang atau tidak senang, puas atau tidak puas dalam bekerja". Setiap individu memiliki tingkat kepuasan yang berbeda-beda, hal ini disebabkan karena adanya perbedaaan tingkat kepuasan dan kebutuhan dari masing-masing pihak.

Sistem penilaian kinerja tidak hanya berguna untuk mengevaluasi kerja karyawan, tetapi juga untuk mengetahui tingkat kepuasan kerja karyawan yang menyebabkan terjadinya peningkatan atau penurunan kinerja karyawan, sehingga akan memberikan feed back yang tepat untuk keberlangsungan perusahaan.Keberhasilan suatu perusahaan sangat dipengaruhi oleh kepuasan kerja karyawannya. Setiap organisasi atau perusahaan akan selalu berusaha meningkatkan kepuasan kerja karyawannya dengan harapan apa yang menjadi tujuan perusahaan akan tercapai. Salah satu cara yang ditempuh oleh perusahaan dalam meningkatkan kepuasan kerja karyawan adalah melalui pemberian kompensasi yang layak. Apabila karyawan merasa puas dengan pekerjaannya maka karyawan tersebut akan semangat dan bergairah dalam melaksanakan tugas-tugas dan pekerjaan, kinerja karyawan akan 
meningkat dan akan bekerja lebih produktif dan memberikan kontribusi positif yang maksimal terhadap perusahaan.

PT. Riau Power merupakan salah satu anak perusahaan dari Badan Usaha Milik Daerah Riau yaitu Riau Investment Corporation yang bergerak dibidang pelayanan jasa Pembangkit Listrik Tenaga Uap-Gas (PLTGU). Pencapaian tujuan dari organisasi tak lepas dari pencapaian kinerja pada karyawannya. Hal itu dapat dilihat untuk mengukur sejauh mana tingkat prestasi dari kinerja karyawan. Berdasarkan data Key Perforrmance Indeks (KPI) PT. Riau Power selalu berubah secara fluktuasi tiap tahunnya, yaitu pada tahun 2014 sebesar $88 \%$ dalam kualifikasi Baik, pada tahun 2015 sebesar $90 \%$ dalam kualifikasi sangat baik, pada tahun 2016 sebesar $85 \%$ dalam kualifikasi baik, tahun 2017 80\% dalam kualifikasi baik dan pada tahun 2018 sebesar70\% dalam kualifikasi cukup.

Untuk mengukur kinerja karyawan pada PT. Riau Power, dapat dilihat melalui Raport yang mereka terima pertahunnya berdasarkan lembar kerja harian karyawan. Pada lembar kerja harian terdapat target kerja karyawan yang digunakan untuk perhitungan remonisasi.

Berdasarkan data kondisi PT. Riau Power Pekanbaru dapat disimpulkan yang menjadi latar belakang sebagai berikut:

1. Tidak adanya penghargaan dan insentif pada karyawan berprestasi.

2. Tidak adanya kenaikan jabatan pada karyawan yang memiliki kinerja baik sehingga karyawan kurang terdorong untuk bekerja dengan maksimal

3. Keadaan dan fasilitas perusahaan yang masih kurang memadai untuk melakukan pekerjaan dapat menyebabkan para karyawan tidak semangat untuk bekerja dan dapat menghambat proses pekerjaan sehingga menyebabkan berkurangnya pencapaian kinerja pada karyawan.

4. Adanya penunggakan gaji yang terjadi dimulai pada awal tahun 2018

5. Mengalami penurunan key performance indeks karyawan setiap tahunnya

Eko dan Bisnis (Riau Economics and Business Reviewe) Volume 10, Nomor 4, 27 Desember 2019
Berdasarkan latar belakang masalah yang telah penulis kemukakan diatas maka permasalahan pokok yang dapat dirumuskan adalah: Apakah Motivasi dan Kepuasan Kerja secara simultan dan parsial Berpengaruh Terhadap Kinerja Karyawan PT. Riau Power?.

\section{Motivasi Kerja}

Motivasi menurut Danang Sunyoto (2013:1) adalah sebagai keadaan yang mendorong keinginan individu untuk melakukan kegiatan-kegiatan tertentu untuk mencapai keinginannya. Menurut Edi Sutrisno (2010:111), motivasi merupakan komponen yang terdiri dari komponen dalam dan komponen luar. Komponen dalam adalah kebutuhan-kebutuhan yang ingin dipuaskan, sedangkan komponen luar adalah tujuan yang hendak dicapai.

Menurut Dr. H Malayu S.P Hasibuan (2013:95) mengungkapkan bahwa motivasi adalah pemberian daya penggerak yang menciptakan kegairahan kerja seseorang agar mereka mau bekerja sama, bekerja efektif dan terintegrasi dengan segala upanya untuk mencapai kepuasan.

Menurut Fahmi (2014:190), motivasi adalah aktivitas perilaku yang bekerja dalam usaha memenuhi kebutuhankebutuhan yang diinginkan. Hal ini juga sejalan dengan pendapat Wayne F. Cascio dalam Sunyoto (2013:11), motivasi adalah suatu kekuatan yang dihasilkan dari keinginan seseorang untuk memuaskan kebutuhannya, misalnya rasa lapar, haus, dan dahaga.

Selanjutnya menurut Kadarisman (2012:278), motivasi adalah penggerak atau pendorong dalam diri seseorang untuk berperilaku dan bekerja dengan giat dan baik sesuai dengan tuags dan kewajiban yang telah diberikan kepadanya.

Sedangkan menurut Andri Feriyanto dan Endang shyta (2015:71) Motivasi adalah suatu sugesti atau dorongan yang muncul karena diberikan oleh seseorang kepada orang lain atau dari diri sendiri.motivasi juga bisa diartikan sebagai sebuah alasan yang mendasari sebuah 
perbuatan yang dilakukan seseorang. Motivasi adalah proses yang menjelaskan intensitas, arah, dan ketekunan seorang individu untuk mencapai tujuannya. Motivasi merupakan satu penggerak dari dalam hati seseorang untuk melakukan atau mencapai sesuatu tujuan. Motivasi juga bisa dikatakan sebagai rencana atau keinginan untuk menuju kesuksesan dan menghindari kegagalan hidup. Dengan kata lain motivasi adalah sebuah proses untuk tercapainya suatu tujuan. Seseorang yang mempunyai motivasi berarti ia telah mempunyai kekuatan untuk memperoleh kesuksesan dalam kehidupan.

Dengan demikian motivasi di dalam kehidupan suatu organisasi harus diamati secara cermat, karena di dalam organisasi akan terjadi hal-hal sebagai berikut (Danang Sunyoto, 2013: 1):

1. Proses kerja sama antara pimpinan dengan bawahan maupun dengan atasan pimpinan itu sendiri.

2. Dalam proses interaksi itu terjadi perilaku bawahan yang diperhatikan, tetapi kemungkinan juga dilaksanakan agar perilaku tersebut sesuai dengan keinginan yang diharapkan.

3. Perilaku yang ditampilkan oleh bawahan yang berjalan dengan sistem nilai atau ketentuan yang berlaku dalam organisasi yang bersangkutan.

Bentuk-bentuk motivasi menurut Fahmi (2014) bentuk motivasi adalah sebagai berikut:

1. Motivasi Ekstrinsik (dari luar) Motivasi Ekstrinsik muncul dari luar diri seseorang, kemudian selanjutnya mendorong orang tersebut untuk membangun dan menumbuhkan semangat motivasi pada diri orang tersebut untuk mengubah seluruh sikap yang dimiliki olehnya saat ini kearah yang lebih baik.

2. Motivasi intrinsik (dari dalam diri)Motivasi intrinsik adalah motivasi yang muncul dan tumbuh serta berkembang dalam diri orang tersebut, yang selanjutnya kemudian mempengaruhi dia dalam melakukan

Eko dan Bisnis (Riau Economics and Business Reviewe) Volume 10, Nomor 4, 27 Desember 2019 sesuatu serta bernilai dan berarti. Motivasi dalam organisasi menurut Suwatno dan Priansa (2011:172) terdapat 3 model motivasi yaitu:

3. Model Tradisional. Model ini mengisyaratkan bahwa manajer menentukan bagaimana pekerjaanpekerjaan harus dilakukan dan digunakannya sistem pengupahan intensif untuk memotivasi para pekerja. Lebih banyak berproduksi, lebih banyak menerima penghasilan. Model ini menganggap bahwa para pekerja pada dasarnya malas dan hanya dapat dimotivasi dengan penghargaan berwujud uang. Dalam banyak situasi pendekatan ini cukup efektif.

a. Model hubungan manusiawi Hubungan manusiawi lainnya menemukan bahwa kontak kontak sosial karyawan pada pekerjaannya adalah juga penting dan bahwa kebosanan dan tugas-tugas yang bersifat pengulangan adalah faktorfaktor pengurang motivasi. Manajer dapat memotivasi bawahan melalui pemenuhan kebutuhan-kebutuhan sosial mereka dan membuat mereka merasa berguna dan penting. Sebagai hasilnya, para karyawan diberi berbagai kebebasan untuk membuat keputusan sendiri dalam pekerjaannya.

b. Model Sumber Daya Manusia Model ini menyatakan bahwa para karyawan dimotivasi oleh banyak faktor, tidak hanya uang atau keinginan untuk mencapai kepuasan tetapi juga kebutuhan untuk berprestasi dan memperoleh pekerjaan yang berarti.

\section{Indikator Motivasi}

Menurut Teori Maslow dalam Mangkunegara (2016:95) indikator motivasi kerja antara lain:

1. Kebutuhan fisiologi, yaitu kebutuhan untuk makan, minum, perlindungan fisik, bernapas, seksual. Kebutuhan ini merupakan kebutuhan tingkat terendah

P.ISSN: 1410-7988 E.ISSN: 2614-123X 
atau disebut pula sebagai kebutuhan yang paling dasar.

2. Kebutuhan rasa aman, yaitu kebutuhan akan perlindungan dari ancaman, bahaya, pertentangan dan lingkungan hidup.

3. Kebutuhan untuk merasa memiliki (Sosial), yaitu kebutuhan untuk diterima oleh kelompok, berafiliasi, berinteraksi dan kebutuhan untuk mencintai serta dicintai.

4. Kebutuhan akan penghargaan, yaitu kebutuhan untuk dihormati, dan dihargai oleh orang lain, status,reputasi,perhatian dan sebagainya.

5. Kebutuhan untuk mengaktualisasi diri yaitu kebutuhan untuk menggunakan kemampuan, skill, dan potensi. Kebutuhan untuk berpendapat dengan mengemukakan ide-ide memberi penilaian dan kritik terhadap sesuatu.

\section{Kepuasan Kerja}

Salah satu sasaran manajemen sumber daya manusia dalam suatu perusahaan adalah terciptanya kepuasan kerja anggota organisasinya. Kepuasan kerja karyawan yang tinggi cenderung akan meningkatkan produktivitas kerja karyawan yang juga akan berdampak positif pada pencapaian tujuan perusahaan. Menurut Veithzal Rivai (2011:856) mengatakan "Kepuasan kerja adalah evaluasi yang menggambarkan seseorang atas perasaan sikapnya senang atau tidak senang, puas atau tidak puas dalam bekerja". Sedangkan Sondang P Siagian (2011:295) berpendapat bahwa "Kepuasa kerja adalah suatu cara pandang seseorang baik yang bersifat positif maupun yang bersifat negatif tentang pekerjaannya". Untuk mengukur kepuasan kerja seorang karyawan menurut Veithzal Rivai (2010: 860) adalah menggunakan: 1) Isi pekerjaan, penampilan tugas pekerjaan yang actual dan sebagai kontrol terhadap pekerjaan 2) Supervisi 24 3) Organisasi dan manajemen 4) Kesempatan untuk maju 5) Gaji dan keuntungan dalam bidang financial lainnya seperti adanya insentif 6) Rekan kerja 7) Kondisi pekerjaan.

Eko dan Bisnis (Riau Economics and Business Reviewe) Volume 10, Nomor 4, 27 Desember 2019

\section{Kinerja}

Istilah kinerja berasal dari kata job performance atau actual performance (prestasi kerja atau prestasi sesungguhnya yang dicapai oleh seseorang).Pengertian kinerja (prestasi kerja) adalah hasil kerja secara kualitas dan kuantitas yang dicapai oleh seorang karyawan dalam melaksanakan tugasnya sesuai dengan tanggung jawab yang diberikan kepadanya. (Anwar Prabu Mangkunegara, 2011:67). Menurut Emron Edison, dkk (2016:190) kinerja adalah hasil dari suatu proses yang mengacu dan diukur selama periode waktu tertentu berdasarkan ketentuan atau kesepakatan yang telah ditetapkan sebelumnya.

\section{Indikator Kinerja}

Pengukuran kinerja berkaitan dengan hasil yang dapat dikuantitatifkan dan mengusahakan data setelah kejadian. Sementara itu indikator kinerja di pakai untuk aktifitas yang hanya dapat ditetapkan secara lebih kualitatif atas dasar perilaku yang dapat diamati.

Menurut Bernardin dan Russel dalam Edi sutrisno (2010:179), untukmengukur kinerja dapat digunakan indikator sebagai berikut:

a) Quality (Kualitas). Merupakan tingkat sejauh mana proses atau hasil pelaksanaan kegiatan mendekati kesempurnaan atau mendekati tujuan yang diharapkan.

b) Quantity (Kuantitas). Merupakan jumlah yang dihasilkan, misalnya jumlah rupiah, unit dan siklus kegiatan yang dilakukan.

c) Timeliness (Ketepatan waktu). Merupakan sejauh mana suatu kegiatan yang dilakukan pada waktu yang dikehendaki dengan memperhatikan koordinasi output lain serta waktu yang tersedia untuk kegiatan orag lain.

d) Cost effectiveness (Efektifitas). Merupakan tingkat sejauh mana penggunaan sumber daya organisasi (manusia, keuangan, teknologi, dan

P.ISSN: 1410-7988 E.ISSN: 2614-123X 
material) dimaksimalkan untuk mencapai hasil tertinggi atau pengurangan kerugian dari setiap unit penggunaan sumber daya.

e) Need for supervision (Keperluan Pengawasan). Merupakan tingkat sejauh mana seorang pekerja dapat melaksanakan suatu fungsi pekerjaan tanpa memerlukan pengawasan seorang supervisor untuk mencegah tindakan yang kurang diinginkan.

f) Interpersonal Impact (Dampak antar pribadi). Merupakan tingkat sejauh mana karyawan memelihara harga diri, nama baik, dan kerja sama diantara rekan kerja dan bawahan.

\section{Pengaruh Motivasi dan kepuasan kerja terhadap Kinerja Karyawan}

Menurut Luthans dalam Juliansyah Noor (2016:87), motivasi kerja berpengaruh langsung terhadap kinerja (work motivation has direct effect performance). Motivasi adalah usaha atau tingkat bagi seseorang yang bekerja keras untuk melakukan pekerjaan dengan baik. Makin jelas, dan makin spesifik tujuan yang ditargetkan maka makin tinggi kinerja yang akan dicapai. Menurut Griffin dalam Julinsyah Noor (2016:87), motivation explain some of the factors involved in increasing the potential for motivated behavior directed at enhanced performance (Motivasi sebagian dari faktor yang dilibatkan dalam meningkatkan potensi untuk perilaku termotivasi yang diarahkan pada peningkatan kinerja).

Pengaruh antara motivasi dan kinerja seseorang sangat erat. Jika seorang karyawan termotivasi untuk melakukan pekerjaannya, maka kinerjanya akan meningkat. Demikian pula sebaliknya jika motivasi seseorang menurun maka jelas kinerjanya pun akan menurun. Dengan demikian dapat dikatakan bahwa motivasi mempengaruhi kinerja seseorang. Pengaruh kepuasan kerjaterhadap kinerja karyawan adalah tinggi rendahnya tingkat kepuasan kerja karyawan yang dirasakan akan mempengaruhi kinerja karyawan. Apabila kepuasan kerja tercapai maka kinerja karyawan atas organisasi tinggi.

Eko dan Bisnis (Riau Economics and Business Reviewe) Volume 10, Nomor 4, 27 Desember 2019
METODE

Jenis dan sumber data yang digunakan dalam penelitian ini adalah :

a. Data Primer yaitu data pokok yang diperoleh dengan cara pengamatan atau survey ke lapangan dengan menggunakan semua metode pengumpulan data original (Roni Andespa, 2012:172). Data primer penulis peroleh langsung dari objek penelitian melalui observasi dan kuesioner dengan karyawan PT. Riau Power Pekanbaru.

b. Data Sekunderyaitu data yang telah dikumpulkan oleh lembaga pengumpul data, yang telah dipublikasikan kepada masyarakat pengguna data (Roni Andespa, 2012:172). Data sekunder yang penulis gunakan adalah data mengenai jumlah karyawan, struktur organisasi, rincian pekerjaan dan laporan tahunan PT. Riau Power Pekanbaru.

\section{Populasi dan Sampel}

Populasi adalah wilayah generalisasi yang terdiri atas objek/subjek yang mempunyai kuantitas dan karakteristik tertentu yang ditetapkan oleh peneliti untuk dipelajari dan kemudian ditarik kesimpulannya (Sugiyono, 2010:148). Populasi dalam penelitian ini adalah seluruh karyawan PT. Riau Power sebanyak 34 karyawan.

Sampel merupakan sebagian dari populasi yang dijadikan sumber memperoleh informasi yang dibutuhkan pada penelitian. Penelitian ini menggunakan teknik sampel jenuh yaitu semua populasi dijadikan sampel karena jumlah populasi relatih kecil (Sugiyono,2010:156) yaitu sebanyak 34 Karyawan

\section{Teknik Pengumpulan Data}

Untuk keperluan analisis data, maka peneliti memerlukan sejumlah data pendukung yang berasal dari dalam dan luar perusahaan. Oleh karena itu, peneliti menggunakan dua macam cara pengumpulan data sebagai berikut:

$$
\text { P.ISSN: 1410-7988 E.ISSN: 2614-123X }
$$




\section{Observasi}

Observasi yaitu mengadakan interview dan tanya jawab secara langsung atau pengamatan secara langsung dengan personel yang terkait dengan objek penelitian.

\section{Kuesioner (Angket)}

yaitu teknik pengumpulan data dengan cara membagikan sejumlah pertanyaan dengan responden. Adapun penentuan skor dari setiap pertanyaan dengan jawaban yang berbeda yaitu: (Sugiyono, 2010:107)

$\begin{array}{ll}\text { Sangat Setuju } & =5 \\ \text { Setuju } & =4 \\ \text { Cukup Setuju } & =3 \\ \text { Tidak Setuju } & =2 \\ \text { Sangat Tidak Setuju } & =1\end{array}$

\section{Teknik Analisis Data}

1. Analisa deskriptif, yaitu data yang disusun merupakan kelompok sedemikian rupa, lalu ditabulasikan dan kemudian dihubungkan dengan teoriteori yang berkaitan dengan permasalahan yang dihadapi perusahaan untuk diambil kesimpulan yang berlaku umum (Roni Andespa, 2012:210).

2. Analisa kuantitatif, adalah jenis data dalam bentuk angka-angka atau bilangan. Sesuai dengan bentuknya, data kuantitatif dapat diolah atau dianalisis menggunakan teknik perhitungan matematika atau statistik. Pengisian kuesioner diukur dengan menggunakan skala likert. Skala likert menurut Umar (2011: 70) yaitu masing - masing jawaban responden diberi bobot $1-5$ yaitu Sangat Setuju (SS), Setuju (S), Cukup Setuju (CS), Tidak Setuju (TS), dan Sangat Tidak Setuju (STS). Kemudian untuk mengetahui rata - rata jawaban responden digunakan interval kelas.

\section{Uji Validitas}

Validitas adalah tingkat keandalan dan kesahihan alat ukur yang digunakan. Instrumen dikatakan valid berarti menunjukkan alat ukur yang dipergunakan untuk mendapatkan data itu valid atau dapat digunakan untuk mengukur mengukur apa yang seharusnya di ukur. (Sugiyono, 2010:137) Dengan demikian, instrumen yang valid merupakan instrumen yang benar-benar tepat untuk mengukur apa yang hendak di ukur. Uji validitas berguna untuk mengetahui apakah ada pernyataanpernyataan pada kuesioner yang harus dibuang/diganti karena dianggap tidak relevan.

Pengujian uji validitas dengan menggunakan uji dua sisi dengan taraf signifikansi 0,05. Kriteria Pengujian adalah sebagai berikut : (Priyatno, 2008:18)

(a) Jika $r$ hitung $>r$ tabel (uji 2 sisi dengan sig 0,05) maka instrumen atau itemitem pertanyaan berkorelasi signifikan terhadap skor total (dinyatakan valid).

(b) Jika $r$ hitung $<r$ tabel (uji 2 sisi dengan sig 0,05) maka instrument atau itemitem pertanyaan tidak berkorelasi signifikan terhadap skor total (dinyatakan tidak valid).

\section{Uji Reliabilitas}

Uji reliabilitas berguna untuk menetapkan apakah instrument yang dalam hal ini kuesioner dapat digunakan lebih dan satu kali, paling tidak oleh responden yang sama akan menghasilkan data yang konsisten. Dengan kata lain, reliabilitas instrumen mencirikan tingkat konsistensi. Nilai Cronbach Alpha> 0,60 yang baik adalah diatas 0,60 (kuat), di atas 0,80 (sangat kuat). (Sugiyono, 2010:214).

\section{Uji Asumsi Klasik}

Penelitian ini menggunakan uji asumsi klasik untuk menguji apakah model regresi dalam penelitian ini telah baik dan tidak bias. Uji asumsi klasik yang digunakan dalam penelitian ini yaitu :
a. Uji Normalitas
b. Uji Multikolineritas
d. Uji Heterokedastisitas 


\section{Analisis Regresi Linier Berganda}

Dalam melakukan analisa data terhadap data yang dikumpulkan, penulis menggunakan metode regresi linier berganda, yaitu hubungan antara dua variabel dependen dengan suatu variabel independen. Persamaan regresi linier berganda digunakan untuk mengetahui pengaruh variabel bebas (X) terhadap variabel terikat (Y). Uji F (Uji Simultan) Uji F dilakukan guna mengetahui pengaruh antar kedua variabel independen yaitu motivasi Kerja dan kepuasan Kerja secara bersama-sama terhadap variabel dependen yaitu kinerja Karyawan.

Adapun persamaan dari regresi linier sederhana adalah sebagai berikut (Sugiyono, 2010:216-262), dimana:

$$
\begin{aligned}
\mathrm{Y}=\mathrm{a}+\mathrm{bX} 1+\mathrm{bX} 2+\varepsilon \\
\text { Keterangan : } \\
\mathrm{Y} \quad=\text { kinerja pegawai } \\
\mathrm{X} 1 \quad=\text { motivasi kerja } \\
\mathrm{X} 2 \quad=\text { Kepuasan Kerja }
\end{aligned}
$$

\section{Uji Signifikan (uji t )}

Digunakan untuk mengetahui pengaruh dan masing-masing variabel, baik variabel bebas terhadap variabel terikat yang signifikan secara statistik.

a. Menentukan Hipotesis

$\mathrm{H}_{\mathrm{o}}$ : tidak ada hubungan secara signifikan antara variabel independent dengan variabel Dependent.

$\mathrm{H}_{\mathrm{a}}$ : Ada hubungan secara signifikan antara variabel independent dengan variabel dependent.

b. Menentukan tingkat signifikan

Pengujian menggunakan uji dua sisi dengan tingkat signifikan $a=5 \%$ (uji dilakukan 2 sisi karena untuk mengetahui ada atau tidaknya hubungan yang signifikan, jika 1 sisi digunakan untuk mengetahui hubungan lebih kecil atau lebih besar).

c. Menentukan t hitung

d.Menentukan $t$ tabel

Tabel distribusi $\mathrm{t}$ dicari pada $\mathrm{a}=5 \%$ :

$2=2,5 \%$ (uji 2 sisi) dengan derajat kebebasan $(\mathrm{df})=\mathrm{n}-\mathrm{k}-\mathrm{l}$

Kriteria pengujian

Eko dan Bisnis (Riau Economics and Business Reviewe) Volume 10, Nomor 4, 27 Desember 2019
Ho diterima jika $-\mathrm{T}$ hitung $>\mathrm{T}$ tabel

Ho ditolak jika $-\mathrm{T}$ Hitung $<\mathrm{T}$ Tabel

Berdasarkan probabilitas:

Ho diterima jika $\mathrm{P}$ value $>0,05$

Ho ditolak jika $P$ value $<0,05$

e. Membandingkan $t$ hitung dengan $t$ tabel dan probabilitas.

\section{Koefisien Determinasi $\left(\mathbf{R}^{\mathbf{2}}\right)$}

Koefisien determinasi pada intinya mengukur seberapa jauh kemampuan model persamaan regresi (independen variabel) dalam menerangkan variasi terikat. Nilai koefisien determinasi adalah antara nol dan satu. Nilai $\mathrm{R}^{2}$ yang kecil berarti kemampuan variabel-variabel bebas dalam menjelaskan variasi variabel terikat sangat terbatas. Nilai yang mendekati satu berarti variabel-variabel bebas memberikan hampir semua informasi yang dibutuhkan untuk memprediksi variabel - variabel terikat.

\section{HASIL}

\section{Uji Validitas}

Hasil uji variabel motivasi, Kepuasan kerja dan kinerja dapat dilihat nilai r_hitung untuk masing-masing item pernyataan pada variabel ketiga variabel tersebut lebih besar ( $>$ ) dari nilai r_tabel (0338), maka dapat disimpulkan bahwa data sudah sesuai dengan keadaan yang sebenarnya atau data sudah valid

\section{Uji Reliabilitas}

Dalam penelitian ini metode yang digunakan adalah dengan metode Cronbach's Alpha yang mensyaratkan nilai Cronbach's Alpha > 0,60 maka data adalah relibel atau dapat dipercaya. Berikut hasil uji reliabilitas dimana Cronbach's Alpha > 0,60 .

\begin{tabular}{|l|r|r|r|r|}
\hline & $\begin{array}{c}\text { Scale Mean if } \\
\text { Item Deleted }\end{array}$ & $\begin{array}{c}\text { Scale } \\
\text { Variance if } \\
\text { Item Deleted }\end{array}$ & $\begin{array}{c}\text { Corrected } \\
\text { Item-Total } \\
\text { Correlation }\end{array}$ & $\begin{array}{c}\text { Cronbach's } \\
\text { Alpha if Item } \\
\text { Deleted }\end{array}$ \\
\hline motivasi & 67,26 & 156,140 &, 805 &, 860 \\
\hline Kepuasan & 77,21 & 157,502 &, 811 &, 854 \\
\hline Kinerja & 69,18 & 185,119 &, 813 &, 861 \\
\hline Sumber : Hasil Olahan SPSS versi 24.00 &
\end{tabular}




\section{Uji Normalitas}

Uji ini dilakukan untuk mengetahui bahwa data yang adalah sah (tidak terdapat penyimpangan).

\section{Grafik Normal Probability Plot}

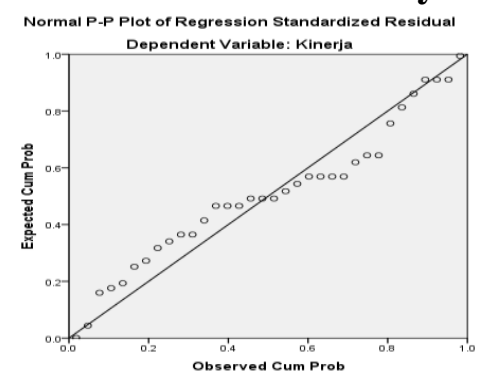

Berdasarkan hasil normal Probability Plot dapat dilihat bahwa data menyebar disekitar garis diagonal dan mengikuti arah garis diagonal. Berdasarkan uji normalitas yang telah dijabarkan diatas dapat disimpulkan bahwa analisa data dengan model regresi linear yang baik dan memenuhi asumsi normalitas data.

\section{Uji Multikolineritas}

Uji multikolinieritas bertujuan untuk menguji apakah model regresi ditemukan adanya korelasi antar variabel bebas. Model regresi yang baik seharusnya tidak terjadi korelasi diantara variabel bebas. Nilai korelasi tersebut dapat dilihat dari colliniearity statistics, apabila nilai VIF (Variance Inflation Factor) memperlihatkan hasil yang lebih besar dari 10 dan nilai tolerance tidak boleh lebih kecil dari 0,1 maka menunjukkan adanya gejala multikolinieritas, sedangkan apabila nilai VIF kurang dari 10 dan nilai tolerance lebih besar dari 0,1 maka gejala multikolinieritas tidak ada. Berdasarkan hasil SPSS diperoleh tidak terjadi gejala multikolinieritas atau terbebas dari Multikolinieritas.

\section{Uji Heterokedastisitas}

Uji heteroskedastisitas bertujuan menguji apakah dalam model regresi terjadi ketidaksamaan variance dari residual satu pengamatan ke pengamatan yang lain. Jika variance dari residual satu pengamatan ke pengamatan lain tetap, maka disebuthomoskedastisitas dan jika berbeda disebut heterokedastisitas.

\section{Regresi Linier Berganda}

Analisis regresi linier berganda yaitu analisis yang bertujuan untuk mengetahui ada tidaknya hubungan ketergantungan, dan arah hubungan ketergantungan antara dua atau lebih variabel bebas dengan variabel terikat apakah positif atau negatif. Adapun persamaan regresi linier bergandanya adalah sebagai berikut:

\begin{tabular}{|c|c|c|c|c|c|c|}
\hline \multicolumn{7}{|c|}{ Coefficients $^{\mathrm{a}}$} \\
\hline & & \multicolumn{2}{|c|}{$\begin{array}{l}\text { Unstandardized } \\
\text { Coefficients }\end{array}$} & \multirow{2}{*}{\begin{tabular}{|c|}
$\begin{array}{c}\text { Standardized } \\
\text { Coefficients }\end{array}$ \\
Beta
\end{tabular}} & \multirow[b]{2}{*}{$\mathrm{t}$} & \multirow[b]{2}{*}{ Sig. } \\
\hline \multicolumn{2}{|c|}{ Model } & B & Std. Error & & & \\
\hline \multirow[t]{3}{*}{1} & (Constant) & $-6,789$ & 4,817 & & $-1,409$ & 169 \\
\hline & Motivasi & 407 & 159 & 412 & 2,567 & 015 \\
\hline & \begin{tabular}{|l|} 
Kepuasan \\
\end{tabular} & .539 & 191 & .454 & 2,825 & 008 \\
\hline
\end{tabular}

$\mathrm{Y}=-6,789+0,407+0,539+\mathrm{e}$

\section{Uji T}

\section{Pengaruh Motivasi Terhadap Kinerja}

Uji $t$ digunakan untuk melihat hubungan variabel bebas (X) terhadap variabel terikat $(\mathrm{Y})$, untuk menunjukkan apakah variabel bebas mempunyai Pengaruh yang signifikan terhadap variabel terikat. Dimana untuk mengetahuinya dengan membandingkan antara nilai $t_{\text {tabel }}$ dengan nilai $t_{\text {hitung. Jika }} t_{\text {hitung }}>$ nilai $t_{\text {tabel }}$ maka variabel $\mathrm{X}$ berpengaruh terhadap variabel $\mathrm{Y}$ dan sebaliknya jika $\mathrm{t}_{\text {hitung }}<$ nilai $\mathrm{t}_{\text {tabel }}$ maka variabel $\mathrm{X}$ tidak berpengaruh terhadap variabel $\mathrm{Y}$. selanjutnya untuk nilai $\mathrm{t}_{\text {tabel }}$ diperoleh dari tabel $\mathrm{t}$ dimana pada taraf signifikan 0,05 dan jumlah responden 34 maka diperoleh nilai $t_{\text {tabel }}$ sebesar $=2,036$ sedangkan nilai $t_{\text {hitung }}$ dapat dilihat pada tabel sebesar 2,567. Sehingga hasilnya berpengaruh dan signifikan

\section{Pengaruh Kepuasan Kerja Terhadap Kinerja \\ Uji $\mathrm{T}$ untuk pengaruh kepuasan} kerja terhadap kinerja yaitu nilai $t_{\text {tabel }}$ diperoleh dari tabel $\mathrm{t}$ dimana pada taraf signifikan 0,05 dan jumlah responden 34 maka diperoleh nilai $t_{\text {tabel }}$ sebesar $=2,036$ sedangkan nilai $t_{\text {hitung }}$ dapat dilihat pada 
tabel yaitu sebesar 2,825 juga berpengaruh dan signifikan.

\section{Uji F}

\section{Pengaruh Motivasi dan Kepuasan Kerja Terhadap Kinerja}

Uji statistik $F$ pada dasarnya menunjukkan apakah semua variabel independen atau bebas yang dimasukkan berpengaruh secara bersama-sama terhadap variabel dependen atau terikat . Cara pengujiannya adalah berdasarkan probabilitas. Bila probabilitas lebih besar daripada 0,05 , maka variabel bebas secara serentak tidak berpengaruh variabel terikat. Sedangkan bila probabilitas lebih kecil daripada 0,05 , maka variabel bebas secara serentak berpengaruh terhadap variabel terikat

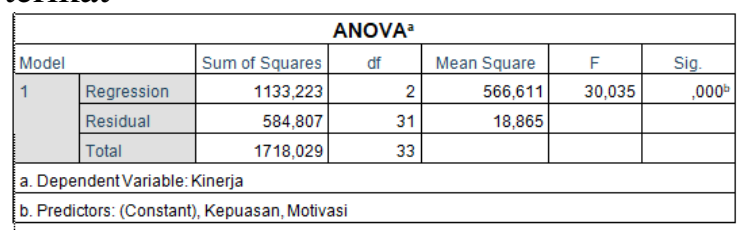

\begin{tabular}{|l|c|r|r|r|}
\hline \multicolumn{5}{|c|}{ Model Summary } \\
\hline Model & R & R Square & $\begin{array}{c}\text { Adjusted R } \\
\text { Square }\end{array}$ & $\begin{array}{r}\text { Std. Error of } \\
\text { the Estimate }\end{array}$ \\
\hline 1 & $812^{\mathrm{a}}$ &, 660 &, 638 & 4,343 \\
\hline a. Predictors: (Constant), Kepuasan, Motivasi \\
\hline
\end{tabular}

Berdasarkan tabel koefisein determinasi diatas diperoleh angka $\mathrm{R}$ square $\left(\left(R^{2}\right)\right.$ sebesar 0,660 atau $34,0 \%$. Hal ini menunjukkan bahwa variabel bebas motivasi dan kepuasan kerja berpengaruh terhadap variabel terikat kinerja adalah sebesar 34,0\% sedangkan $66,0 \%$ dipengaruhi oleh variabel lain.

\section{Pembahasan}

Berdasarkan penelitian ini dapat dijelaskan bahwa motivasi dan kepuasan kerja berpengaruh terhadap kinerja, hal ini bisa dijelaskan bahwa motivasi sangat diperlukan oleh karyawan dalam melaksanakan tugas untuk mencapai kepuasan kerja yang tinggi meskipun menurut sifatnya kepuasan kerja itu sendiri berbeda antara satu orang dengan orang lainnya. Hal ini mengandung arti bahwa semakin meningkat kepusan kerja seorang

Eko dan Bisnis (Riau Economics and Business Reviewe) Volume 10, Nomor 4, 27 Desember 2019 karyawan maka semakin meningkat pula kinerja seorang karyawan. Berdasarkan penelitian ini dapat dijelaskan bahwa kepuasan kerja memang sangat diperlukan oleh seorang karyawan dalam meningkatkan kinerja masing-masing individu meskipun menurut sifatnya kepuasan kerja itu sendiri sangat relatif atau berbeda antara satu orang dengan orang lainnya. Penelitian ini sejalan dengan penelitian yang dilakukan oleh I Wayan Juniantara1 I Gede Riana (2015) pengaruh motivasi dan kepuasan kerja terhadap kinerja karyawan koperasi di Denpasar, hasil penelitian menunjukkan bahwa motivasi dan kepuasan kerja berpengaruh terhadap kinerja. Sehingga perusahaan harus lebih memperhatikan tentang motivasi.

\section{SIMPULAN}

Berdasarkan pembahasan dan analisis yang telah dilakukan sebelumnya dalam penelitian maka dapat disimpulkan sebagai berikut :

1. Motivasi dan Kepuasan Kerja berpengaruh positif dan signifikan secara simultan dan parsial terhadap kinerja karyawan di PT. Riau Power.

2. Nilai R Square sebesar $66 \%$ sedangkan sisanya sebesar $34 \%$ dipengaruhi variabel lain yang tidak diteliti dalam penelitian ini seperti, faktor kecerdasan emosi, kepemimpinan, budaya organisasi dan lain sebagainya. agar dapat mencapai tujuan perusahaan.

\section{DAFTAR RUJUKAN}

Andespa, Roni. 2012. Metodologi Riset Bisnis. Pekanbaru, Al Huda Press.

Edy Sutrisno. 2010. Manajemen Sumber Daya Manusia. Edisi Pertama. Cetakan Pertama. Jakarta : Penerbit Kencana.

Feriyanto Andri dan Triana, Endang Shyta. Pengantar Manajemen, (Yogyakarta: Mediatera, 2015).

Juliansyah Noor. 2012. Metodologi Penelitian: Skripsi, Tesis, Disertasi, dan Karya Ilmiah. Jakarta: Penerbit Kanca Prenada Media Group.

P.ISSN: 1410-7988 E.ISSN: 2614-123X 
Kadarisman, M. (2012). Manajemen

Pengembangan Sumber Daya Manusia.

Jakarta: Rajawali Pers.

Kasmir. 2016. Manajemen Sumber Daya Manusia, PT. Raja Grafindo Persada, Jakarta.

Mangkunegara. 2011. Manajemen Sumber Daya Perusahaan. PT. Remaja Rosdakarya. Bandung.

Stephen, Robbins (2015), Perilaku Organisasi, Penerbit Salemba Empat, Jakarta.

Sugiyono .2015. (Metode Penelitian Kombinasi (Mix Methods). Bandung: Alfabeta.

Rivai, Veitzal. 2010. Manajemen Sumber Daya Manusia untuk PT. Raja Grafindo Perkasa.

Sondang P. Siagian. 2011. Manajemen Sumber Daya Manusia. Jakarta: Bumi Aksara. Jakarta.

Sunyoto, Danang. 2013. Manajemen Sumber Daya Manusia. Penerbit CAPS. Yogyakarta.

Suwatno. \& Priansa, D. 2011. Manajemen SDM dalam organisasi Publik dan Bisnis. Bandung: Alfabeta. 